\title{
The Ban on Tobacco for Oral Use Upheld by the Court of Justice: On Subsidiarity and Proportionality in EU Lifestyle Risks Policy
}

\author{
Vincent DELHOMME*
}

Case C-151/17, Swedish Match AB v Secretary of State for Health, ECLI:EU: $C: 2018: 938$

The prohibition on the placing on the market of tobacco for oral use is not in breach of the EU general principles of non-discrimination, proportionality and subsidiarity, of Articles 296, 34 and 35 TFEU and of Articles 1, 7 and 35 of the Charter.**

\section{INTRODUCTION}

Over the last few decades, tobacco has shaped the law of the internal market in incomparable ways. This is illustrated once more by the recent judgment in Swedish Match AB v Secretary of State for Health, ${ }^{1}$ where the Court of Justice confirmed the validity of the prohibition of tobacco for oral use contained in Directive 2014/40 (the Tobacco Products Directive). ${ }^{2}$

The EU tobacco control policy and its related case law are a textbook example of the fundamental constitutional tensions present in the EU legal order: between the Union and the Member States' competences on the one hand, ${ }^{3}$ between the market and other "social" objectives on the other. The pursuit of a public health agenda with the EU internal market competence of Article 114 TFEU has given rise to several concerns. Not only does it fuel the competence creep feeling, it also subordinates the EU health policy to the goal of market integration. ${ }^{4}$ Both issues appear clearly from the present judgment and the challenges of applying subsidiarity and proportionality to the EU lifestyle policy.

\footnotetext{
* Academic Assistant, College of Europe, Department of European Legal Studies, Bruges, email vincent. delhomme@coleurope.eu; PhD candidate, UCLouvain. I would like to thank Anne-Lise Sibony and an anonymous reviewer for their helpful comments. All remaining errors are mine.

** Arts 1(c) and 17 of Directive 2014/40/EU of the European Parliament and of the Council of 3 April 2014 on the approximation of the laws, regulations and administrative provisions of the Member States concerning the manufacture, presentation and sale of tobacco and related products and repealing Directive 2001/37/EC, [2014] OJ L 127, p 1.

1 Case C-151/17, Swedish Match AB v Secretary of State for Health, ECLI:EU:C:2018:938.

2 Directive 2014/40/EU of the European Parliament and of the Council of 3 April 2014 on the approximation of the laws, regulations and administrative provisions of the Member States concerning the manufacture, presentation and sale of tobacco and related products and repealing Directive 2001/37/EC, [2014] OJ L 127, p 1.

3 See S Weatherill, "The Limits of Legislative Harmonization Ten Years after Tobacco Advertising: How the Court's Case Law has become a 'Drafting Guide"” (2011) 12(3) German Law Journal 827; D Wyatt, "Community Competence to Regulate the Internal Market" (2007) 9/2007 University of Oxford Faculty of Law Legal Studies Research Paper Series 1.

4 V Delhomme, "Between market integration and public health: the paradoxical EU competence to regulate tobacco consumption” (2018) College of Europe Research Paper in Law, 01/2018.
} 


\section{BACKGROUND AND FACTS}

The EU has positioned itself as a key actor in the fight against tobacco consumption, in the framework of its broader commitment to limit the harmful consequences of "lifestyle related risks factors". 5 The Tobacco Products Directive, adopted in its last version in 2014, is a far-reaching instrument that regulates most aspects of the composition and presentation of tobacco products and sets a strict framework for their commercialisation. It has already been subjected to numerous challenges, all rejected by the Court of Justice. ${ }^{6}$

The present case deals more specifically with Articles 1(c) and 17 of the Directive, prohibiting the placing of tobacco for oral use on the European market. This type of product, also known as snus, usually consists of a small sachet containing tobacco placed between the gum and the lips for consumption. It is widely used in Sweden, the only EU country where it is still allowed by virtue of a derogation secured upon the country's accession to the Union. The EU-wide ban has been in place since 1989 and confirmed ever since. ${ }^{7}$

Swedish Match, one of the biggest manufacturers of tobacco for oral use, raised the invalidity under EU law of the prohibition of snus in a challenge before a British court of the national transposition measure. It was joined in these proceedings by the New Nicotine Alliance, a charity whose objective is to promote public health by means of tobacco harm reduction. It is noteworthy that Swedish Match had already contested the validity of this prohibition for lack of EU competence under the previous Directive of $2001,{ }^{8}$ a claim rejected by the Court. ${ }^{9}$ This matter having been settled, the present challenge focuses on the exercise of the competence. ${ }^{10}$

Before continuing with the judgment at hand, it is crucial to have in mind the EU competence framework for enacting public health measures and the problems arising from the first Swedish Match judgment. ${ }^{11}$ Because the Union does not enjoy any standalone competence in public health allowing it to take harmonisation measures, ${ }^{12}$ lifestyle

\footnotetext{
5 Regulation 282/2014 on the establishment of a third Programme for the Union's action in the field of health (20142020) and repealing Decision No 1350/2007/EC [2014] OJ L 86, p 1, Art 3(1); on this policy see A Alemanno and A Garde (eds), Regulating Lifestyle Risks: The EU, Alcohol, Tobacco and Unhealthy Diets, (Cambridge University Press 2015); A Alemanno and A Garde, "The emergence of an EU lifestyle policy: the case of alcohol, tobacco and unhealthy diets" (2013) 50 Common Market Law Review 1745.

6 Case C-547/14, Philip Morris Brands SARL ea v Secretary of State for Health, EU:C:2016:325; Case C-358/14, Poland v European Parliament and Council, EU:C:2016:323; Case C-477/14, Pillbox 38 (UK) Ltd v The Secretary of State for Health, ECLI:EU:C:2016:324.

7 Council Directive 89/622/EEC of 13 November 1989 on the approximation of the laws, regulations and administrative provisions of the Member States concerning the labelling of tobacco products [1989] OJ L 359, p 1.

8 Directive 2001/37/EC of the European Parliament and of the Council of 5 June 2001 on the approximation of the laws, regulations and administrative provisions of the Member States concerning the manufacture, presentation and sale of tobacco products [2001] OJ L 194, p 26.

9 Case C-210/03, Swedish Match AB and Swedish Match UK Ltd v Secretary of State for Health, EU:C:2004:802 and Case C-434/02, Arnold André GmbH \& Co. KG v Landrat des Kreises Herford, EU:C:2004:800.

10 For the distinction between the existence and the exercise of EU competences, see Art 5(1) TEU.

11 Swedish Match, supra, note 9.

12 Art 168(5): "The European Parliament and the Council, acting in accordance with the ordinary legislative procedure and after consulting the Economic and Social Committee and the Committee of the Regions, may also adopt incentive measures designed to protect and improve human health and in particular [...] measures which have as their direct objective the protection of public health regarding tobacco and the abuse of alcohol, excluding any harmonisation of the laws and regulations of the Member States" (emphasis added).
} 
legislation has been enacted under the internal market legal basis of Article 114 TFEU. This provision grants the EU legislator the power to take measures "which have as their object the establishment and functioning of the internal market". ${ }^{13}$ While accepting the integration of public health objectives into internal market legislation, required by the mainstreaming obligation contained in various EU law provisions, ${ }^{14}$ the Court has consistently stressed the need for any such measure to make an effective contribution to the internal market in order to be lawfully adopted. ${ }^{15}$

In the first Swedish Match judgment, the Court decided that the power granted to the EU under Article 114 TFEU included the definitive ban of a product, ${ }^{16}$ while retaining as a general formula the principle that internal market measures must be designed to eliminate obstacles to trade between Member States. ${ }^{17}$ It remains hard to grasp how banning a product on the EU-wide market can be considered as removing obstacles to trade, or even facilitating the smooth functioning of the internal market, ${ }^{18}$ since the very object of this trade becomes ipso facto eliminated. For Advocate General Geelhoed, if the ban of a product cannot be said to improve trading conditions for this product itself, it does however reduce the enforcement costs of regulations on related products and hence improve their trading conditions. ${ }^{19}$ This justification still appears rather unconvincing. ${ }^{20}$ The prohibition of a class of products is a pure public health measure for which the EU does not enjoy any competence. As will appear subsequently, this problem pervades the present judgment.

The parties' submissions rest on several grounds, translating into six questions referred for a preliminary ruling: violation of the principles of non-discrimination, subsidiarity and proportionality, violation of Article 296 TFEU, Articles 34 and 35 TFEU, and violation of Articles 1, 7 and 3 of the Charter of Fundamental Rights. The Court finds no such violation and the present commentary will focus on the questions of subsidiarity and proportionality.

\section{JUDGMENT}

The first question raised by the referring court concerns the alleged infringement by Articles 1(c) and 17 of the Directive of the principle of equal treatment. Swedish Match considers that the prohibition of tobacco for oral use is discriminatory insofar as other kinds of tobacco products are not prohibited, namely other smokeless tobacco products, products for smoking, electronic cigarettes and novel tobacco products. ${ }^{21}$ The Court

13 Art 114(1) TFEU.

14 Arts 9, 114(3), 168(1) TFEU and Art 35 of the Charter of Fundamental Rights of the European Union.

15 Case C-376/98, Germany v European Parliament and Council, EU:C:2000:544.

16 Swedish Match, supra, note 9, para 34, see also Arnold André, supra, note 9, para 35.

17 ibid, paras 30 and 33, see also recently Philip Morris, supra, note 6, paras 59 and 62.

18 See a contrario case Swedish Match II, supra, note 1, para 68.

19 Opinion of Advocate General Geelhoed, Arnold André and Swedish Match, ECLI:EU:C:2004:487, paras 78-79.

20 See Wyatt, supra, note 3, pp 24-28; see also for the prohibition of tobacco with characterising flavour: Opinion of Advocate General Kokott, Philip Morris, ECLI:EU:C:2015:853, para 83, and commentary in Delhomme, supra, note 4, 14-16.

21 Swedish Match II, supra, note 1, para 11. 
dismisses the argument, pointing at the objective differences between tobacco for oral use and all the other categories that can justify a difference in treatment. ${ }^{22}$

On proportionality, Swedish Match claims that the prohibition of tobacco for oral use is neither necessary nor appropriate to the fulfilment of any legitimate objective, and that the precautionary principle cannot be relied on since other tobacco products having a higher toxicity are authorised. ${ }^{23}$ The Court starts by recalling the principles governing the proportionality of EU acts - appropriateness, necessity and respect for the precautionary principle - the Court limiting its control to the presence of a manifest error, especially in areas requiring highly complex scientific and technical assessments. ${ }^{24}$ In the present case, the proportionality of the prohibition of tobacco for oral use has to be evaluated against the double objective pursued by the Directive: facilitating the smooth functioning of the internal market, while taking as a base a high level of protection of human health. ${ }^{25}$

Regarding the public health objective, the Court engages with the various pieces of scientific evidence brought forward. ${ }^{26}$ While it is established that tobacco for oral use is less harmful than tobacco for smoking, the extent to which the first could be used as an aid to the cessation of smoking is uncertain. Lifting the ban would carry a risk of harm for those, especially young people, who would start consuming snus, while the benefits for the current smokers would remain uncertain. In this situation of uncertainty, it is clear for the Court that the choice of the legislator was in line with the precautionary principle and could not be considered as manifestly inappropriate to the objective of ensuring a high level of public health. ${ }^{27}$ Considering the potential for growth in the market and the dangerousness of snus, especially for minors, the Court also considers the decision to prohibit snus as not manifestly exceeding what is necessary. ${ }^{28}$ It adds that the protection of health prevails over economic considerations, such as the potential for growth in the snus market. ${ }^{29}$

Regarding the market objective, the Court also finds the ban to be suitable and necessary, as lifting it would surely lead to a divergence in the laws of the Member States. ${ }^{30}$ Finally, the Court dismisses the argument of Swedish Match based on an alleged lack of consistency insofar other tobacco products are not prohibited, making a reference to its previous conclusions on the principle of equal treatment. ${ }^{31}$

Concerning subsidiarity, Swedish Match considers the prohibition to fall foul of this principle for failing to take account of the particular circumstances of each Member State, contrary to what prevails for other tobacco products for which Member States retain a degree of discretion. ${ }^{32}$ The Court rejects the argument, considering that, even if

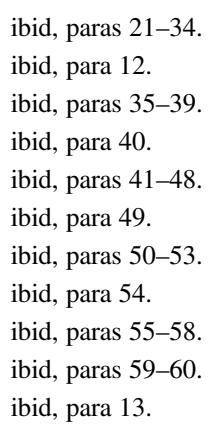


the health objective pursued by the Directive might be better achieved at the national level, this would in any way run completely counter to its internal market objective. ${ }^{33}$ The Court adds that the greater leeway left to Member States regarding other tobacco products is a discretionary choice made by the legislator to harmonise tobacco in stages and does not demonstrate that the objectives of the Directive could be adequately achieved by Member States. ${ }^{34}$

On the breach of the second paragraph of Article 296, according to which "[l]egal acts shall state the reasons on which they are based [... ${ }^{\prime \prime},{ }^{35}$ the Court considers recital 32 of the Directive to be clear enough to enable courts to exercise their power of review. ${ }^{36}$ Equally, the Court does not find any breach of Articles 34 and 35 TFEU, the prohibition of snus being a justified, non-discriminatory and proportionate restriction to free movement of goods. ${ }^{37}$

The final question, brought forward by the New Nicotine Alliance, is based on the alleged breach of Articles 1,7 and 35 of the Charter for depriving consumers who want to avoid smoking of a less toxic alternative. ${ }^{38}$ For the Court, even if this substitution effect was proved and the prohibition of snus subsequently found to be limiting fundamental rights, this prohibition is in itself intended to protect the right to health, as it does not deprive consumers wishing to stop smoking of all means to do so, and is proportionate. There is therefore no breach of the articles of the Charter. ${ }^{39}$

\section{COMMENT}

If compared to the earlier case law on the legality of the EU tobacco policy, the present judgment does not offer important new developments, and rather confirms the principles governing the use of Article 114 TFEU for measures pursing public health objectives. It is yet a very good illustration of the difficulties of properly integrating human health concerns into internal market legislation and, more broadly, to pursue simultaneously both objectives.

\section{Subsidiarity}

The impossibility to pursue public health objectives independently affects subsidiarity control. It is, indeed, inherent to the internal market objective that it cannot be achieved by Member States alone, since it requires harmonisation that only the EU can provide. This means, as expressed by the Court in the present judgment, that although Member States might be better placed to achieve the health objective underlying a measure, the EU will always be better positioned to fulfil the two objectives combined. ${ }^{40}$ The

33 ibid, paras 64-69.

34 ibid, paras 70-75.

35 Art 296(2) TFEU.

36 Swedish Match II, supra, note 1, paras 80-82.

37 ibid, paras 83-85.

38 ibid, para 18.

39 ibid, paras 86-91.

40 See also Philip Morris, supra, note 6, paras 221-222; Poland v European Parliament and Council, supra, note 6, paras $117-118$. 
subsidiarity principle offers no help to challenge a measure where the EU appears to be less well suited than Member State to protect human health, which leads to an unfortunate subordination of health to the goal of market integration.

Interestingly enough, this seems to be the case for the prohibition of tobacco for oral use. Indeed, regarding the use of snus as an aid to stop smoking, the report of the scientific committee on which the Directive is based indicates that "[the] data imply that the association between patterns of smokeless tobacco use and smoking cessation differs between populations and is likely to be affected by cultural, societal and other factors". 41 Hence, a health argument could be made to let Member State decide whether or not to authorise the marketing of snus, but that argument is neutralised by the recourse to a legal basis for which the market objective prevails. This situation is not only damaging, it is also ironical, if one considers that the EU-wide prohibition of tobacco for oral use makes in any case no valid contribution to the functioning of the internal market.

This impossibility to advance health arguments at the subsidiarity level is even more problematic in the case of lifestyle risks factors, such as tobacco or alcohol, for which the Union itself recognises that differences in cultural habits provide a solid ground to let Member States act. ${ }^{42}$ This does not mean that the EU can never be better placed to act, ${ }^{43}$ but when it is not, subsidiarity should offer means to prevent such action. Under the current competence framework, as interpreted by the Court, this is unfortunately impossible.

\section{Proportionality}

The case at hand also offers interesting insights regarding the control of proportionality of lifestyle risks measures.

Unsurprisingly, given the difficulties of construing a total ban on tobacco for oral use as a measure adequately contributing to the smooth functioning of the internal market, the Court's analysis of proportionality with respect to the market objective is extremely limited. It would, however, have been interesting to understand how the Court considers that such a ban is appropriate, necessary and not disproportionate to the fulfilment of this objective, considering once again that no valid argument has been made to date as to how banning snus improves trading conditions for other products.

The Court focuses on the proportionality assessment with respect to the health objective of the measure and offers interesting reflections on the use of the precautionary principle and the intensity of the judicial control of EU legislation.

The regulation of lifestyle risks is characterised, like many areas of EU action, by a certain degree of uncertainty, probably reinforced by the cultural differences and variations in consumption patterns existing at the national level. ${ }^{44}$ Swedish Match refers to studies made in a particular national context, Sweden and Norway, which it argues

\footnotetext{
41 Scientific Committee on Emerging and Newly Identified Health Risks (SCENIHR), "Health Effects of Smokeless Tobacco Products" (2008) European Commission, p 12.

42 Communication from the Commission to the Council, the European Parliament, the European Economic and Social committee and the Committee of the Regions, An EU strategy to support Member States in reducing alcohol related harm, section 1 and 6.2.

43 See Alemanno and Garde (2013), supra, note 5, p 1770.

44 See SCENIHR, supra, note 41, p 12; see Swedish Match II, supra, note 1, para 46.
} 
prove that tobacco for oral use is effective as a replacement for traditional tobacco products and does not create new risks for consumers, ${ }^{45}$ which are deemed inconclusive by the Commission. ${ }^{46}$ But even if considered reliable, these studies would probably not represent sufficient proof to successfully call into question the suitability of the EU prohibition. Indeed, what is considered at this stage is the global European market on which uncertainty is likely to remain precisely because of national differences. Hence, uncertainty arises not only from the complex scientific nature of the matter at stake, but also from the choice to act at the EU level. ${ }^{47}$

In line with the precautionary principle, the Court discards the arguments of the litigants regarding the unsuitability of the ban. It is established that tobacco for oral use presents risks for human health and that these risks are lower than those associated with tobacco for smoking; there is, however, an uncertainty on the effect of lifting the ban. It could have beneficial consequences if consumers used this product to replace more harmful products, but could also have detrimental consequences if it were to incite more people to consume snus, or worse, provide a gateway to smoking. ${ }^{48}$ In light of this uncertainty and in accordance with the precautionary principle, a cost benefit analysis must be performed which should indeed be the prerogative of the legislator. ${ }^{49}$

This part of the judgment is particularly interesting on two levels. It shows clearly that the Court does not shy away from engaging with the scientific evidence brought forward by the parties and present in the ex ante impact assessment. ${ }^{50}$ It also signals the use of the precautionary principle in an original way: not only to grant the legislator the possibility to act when uncertainty exists regarding the existence of a hazard, but also when uncertainty exists "surrounding the effectiveness of a policy option aimed at tackling that hazard" ${ }^{51}$ This mix of increased attention for the evidence gathered during the legislative process and deference for the final political choices made by the legislator is the right approach for the Court to properly discharge its function without overstepping its mandate.

The Court is also right to discard the claimant's argument on the breach of the principle of equal treatment and therefore of the lack of consistency of the EU tobacco policy. Tobacco for oral use is a separate class of products that can perfectly be regulated differently from others. On the comparison between tobacco for oral use and tobacco for smoking, the Court could yet have valuably made its reasoning more explicit. Indeed, it seems prima facie quite incoherent to prohibit snus and not cigarettes, the latter carrying more risks for human health. But as pointed out by the Advocate General, the key

45 Swedish Match II, supra, note 1, para 46.

46 ibid, para 43.

47 On the complexity of lifestyle risks regulation in general, see A Alemanno and A Garde, "The emergence of EU lifestyle risks regulation: new trends in evidence, proportionality and judicial review", in H-W Micklitz and T Tridimas, Risk and EU Law (Edward Elgar 2015) pp 157-158.

48 Swedish Match II, supra, note 1, paras 41-46; see also Opinion of Advocate General Saugmandsgard Øe, Swedish Match II, ECLI:EU:C:2018:241, paras 43-57.

49 Swedish Match II, supra, note 1, para 47, see also Opinion of Advocate General Saugmandsgard Øe, Swedish Match II, supra, note 48, paras 61-62.

50 See also in that regard Case C-58/08, Vodafone, ECLI:EU:C:2010:321; Case C-77/09, Gowan, ECLI:EU: C:2010:803, para 56; Philip Morris, supra, note 6, para 189; K Lenaerts, "The European Court of Justice and Processoriented Review", Research Paper in Law, College of Europe, 01/2012; Alemanno and Garde, supra, note 47.

51 See Alemanno and Garde (2013) supra, note 5, p 1774. 
difference here lies in the fact that prohibiting cigarettes would drive large swathes of the population into the black market and would hence be counter-productive, ${ }^{52}$ a risk inexistent for snus since there is no consumption of it in most EU countries.

Regarding necessity, the Court's answer suffers no contestation. Once it has been established that the prohibition of tobacco for oral use can appropriately fulfil the health objective pursued because this product is detrimental to health, it is indeed difficult to argue that any other measure would be as effective as a complete ban. In any way, determining the exact effect of a given policy in an area where many EU and national measures are in place is a very difficult assessment and discretion should indeed be left to the EU legislator in this regard. ${ }^{53}$ It can only be regretted that this approach does not prevail when the Court scrutinises national measures seeking derogation from the freedoms of movement on grounds of public health. ${ }^{54}$

\section{Fundamental rights}

If the reliance on fundamental rights provision is not unusual in the context of EU tobacco litigation, the argument brought forward by the New Nicotine Alliance in the present case appears quite original. Instead of pleading the infringement of fundamental rights stemming from the economic activity being restricted, freedom of expression and information or freedom to conduct a business, which have been unsuccessfully relied on in numerous occasions, ${ }^{55}$ the NNA argues here that the ban on tobacco for oral use breaches itself the right to health, insofar as it deprives smokers of a cessation aid. ${ }^{56}$

The argument can surely not be accepted considering the present uncertainty regarding the effect of snus on smoking cessation. But the Court's reasoning goes further in saying that no matter the impact of the ban on the right to health, this ban would respect the essence of this right because smokers are not entirely deprived of all means helping them to quit smoking. This appears to be an unfortunate conclusion. If it was proven that snus was the best way to quit smoking, prohibiting it would definitely be a breach of the right to health, regardless of the fact that it is intended "not to restrict the right to health but, on the contrary, to give expression to that right". 57

\section{CONCLUSION}

This judgment is a very good illustration of the paradoxical position of tobacco regulation in the current EU legal framework: it reaches further than the competences

\footnotetext{
52 Opinion of Advocate General Saugmandsgard Øe, Swedish Match II, supra, note 48, para 74.

53 See Alemanno and Garde (2013) supra, note 5, pp 1775-1776; Alemanno and Garde (2015), supra, note 47, pp 160-163.

54 See inter alia Case C-170/04, Rosengren, ECLI:EU:C:2007:313; Case C-333/14, The Scotch Whisky Association, ECLI:EU:C:2015:845. On the latter, see A Alemanno, "Balancing free movement and public health: the case of minimum unit pricing of alcohol in Scotch Whisky" (2016) 53 Common Market Law Review 1037.

55 On freedom of expression and information (Art 11 of the Charter), see Philip Morris, supra, note 6, paras 146-163; Case C-380/03, Germany v European Parliament and Council, ECLI:EU:C:2006:772, paras 144-159; on freedom to conduct a business and the right to property (Arts 16 and 17 of the Charter), see Pillbox, supra, note 6, paras 152-166; Case C-491/01, British American Tobacco, ECLI:EU:C:2002:741, paras 149-150.

56 More precisely Art 1 (human dignity), Art 7 (respect for private and family life) and Art 35 (health care) of the Charter.

57 Swedish Match II, supra, note 1, para 89.
} 
conferred on the EU, which do not include pure public health measures, but it also fails to adequately integrate human health concerns within those measures, ${ }^{58}$ for instance at the subsidiarity level. The mainstreaming obligation cannot justify disregarding the boundaries of the Union's action, but once the prerequisite for this action is fulfilled, it means that health concerns must be properly integrated into internal market legislation.

The Court bears a partial responsibility in this situation. It should not hesitate to annul legal provisions making no contribution to the functioning of the internal market so long the EU is not entrusted with proper powers in the field of health, and should at the same time require the EU legislator to better justify its choices when it appears that the national level can more adequately protect the health of European citizens or that a given measure may not lead to a sufficient high level of health protection.

There is, of course, a more fundamental problem lying with the incoherent and deceptive constitutional framework contained in the Treaties, which fails to delineate properly the respective competences of the EU and its Member States and does not entrust the Union with the powers necessary to the conduct of a fully-fledged public health policy. 59

\footnotetext{
58 See Delhomme, supra, note 4.

59 See R Schütze, From Dual to Cooperative Federalism: The Changing Structure of European Law (Oxford University Press 2009) 282-283; S Garben, "Confronting the Competence Conundrum: Democratising the European Union through an Expansion of its Legislative Powers" (2015) 35(1) Oxford Journal of Legal Studies 75-76.
} 